\title{
The possibilities of water purification using phytofiltration methods: a review of recent progress
}

\author{
EWa J. HaNus-Fajerska *, ALEKSANDRA KoŹMiŃSKa \\ Institute of Plant Biology and Biotechnology, University of Agriculture, \\ Faculty of Biotechnology and Horticulture, Kraków, Poland
}

\begin{abstract}
Contaminated water can be purified using mechanical, chemical, or biological methods. Environmentally safe technology of phytoremediation involving plant metabolism is also an alternative solution. Phytofiltration, classified as one of the most promising among phytoremediation, is a technique that relies on remediation of contaminated water through absorption or precipitation and further concentration of pollutants. Currently, only very few plant species are known to be fully suitable to be used for this technology. Such species can efficiently remove toxic metal ions from a solution because of rapidly grown biomass. The selection of suitable plant material for phytofiltration is still considered the most difficult step, especially when purification of groundwater contaminated with a mixture of compounds is concerned. The advantages of this technique are presented herein, especially in relation to water reservoirs contaminated with trace metals.
\end{abstract}

Key words: phytoremediation, phytofiltration, water pollution, plant species, trace metals

\author{
Abbreviations: \\ TEs - trace elements NMR - nuclear magnetic resonance \\ NMOS - nanosized metal oxides XAS - X-ray absorption spectroscopy;
}

\section{Introduction}

Rapid growth both in the agricultural and industrial sectors during the last several years has improved the living standards of human beings; on the contrary, it has also created serious environmental threats (Adriano, 2001; Adress et al., 2015; Rizwan et al., 2015). Soil and water pollution with trace elements (TEs) are among threats resulting mainly from anthropogenic activities. Negative industrial activities include mining and processing of metallic ores; and apart from these, the excessive use of industrial wastes, sewage sludge, fertilizers, and pesticides, mostly in agricultural sector, creates environmental problems. In contrast, major natural contributors of TEs in the environment are volcanic activity or weathering of parent rock (Nagajyoti et al., 2010). TEs, in general, include biologically essential elements, such as zinc $(\mathrm{Zn})$, cobalt $(\mathrm{Co})$, copper $(\mathrm{Cu})$, and manganese $(\mathrm{Mn})$, chromium $(\mathrm{Cr})$, and non-essential, harmful elements, such as cadmium (Cd), arsenic (As), mercury $(\mathrm{Hg})$, lead $(\mathrm{Pb})$. The essential elements are required in trace amounts for the normal growth and development of plants and animals, and hence they are usually known as micronutrients. However, these elements are toxic to living organisms when present at elevated concentrations (Rahman and Hasegawa, 2011; Zaheer et al., 2015). Since no biological functions of nonessential elements have been identified, they are toxic to plants, animals, and/or humans even at low concentrations (Kabata-Pendias and Pendias, 2001; Wuana and Okieimen 2011; Rizwan et al. 2015). During the water purification process, TEs are exploited either by chemical/physicochemical or biological (biochemical/biosorption) mechanisms. Choosing the appropriate approach, verifying the accuracy of the risk, checking efficiency and cost-effectiveness of methods are crucial for effective treatment of contaminated wastewaters. In some instances, two or

\footnotetext{
* Corresponding author: Institute of Plant Biology and Biotechnology, University of Agriculture, Faculty of Biotechnology and Horticulture, al. 29 Listopada 54, 31-425 Kraków, Poland; e-mail: e.hanus@ogr.ur.krakow.pl
} 
even more of the techniques are used synergistically to achieve better results (Fu and Wang, 2011; Hashim et al., 2011; Czemierska et al., 2015). Attempts are also made either to optimize the existing technologies or to invent a novel use of already known methodologies.

In the present study, we were focused on the domain of phytofiltration, especially in relation to bodies of water contaminated with trace metals. The paper presents a comprehensive review that has been mainly worked out upon the selected results obtained in the last decades. In addition, we propose a consistent overview regarding vascular plant species frequently used in the described technology.

\section{The technology for purification of contaminated water}

The most commonly used methods of physicochemical removal of the metallic elements include ion exchange and membrane filtration. Besides, processes of precipitation, coagulation-flocculation and flotation are also commonly used (Kurniawan et al., 2006; Fu and Wang, 2011; Katsou et al., 2011). The process of biosorption using adsorbents (biomaterials) with functional groups (carboxyl, hydroxyl, sulfhydryl, amide) where metal ions are easily bonded poses an interesting solution. Even though the mechanism of biosorption may seem quite complicated because it requires several different processes, such as adsorption, surface precipitation, ion exchange, or complexation, it is known for the efficient and cost-effective approach. However, some high-performing materials (e.g., straw or bran of wheat) can be applied (Farooq et al., 2010; Wiszniewska et al., 2016). Various types of vegetable waste can also be successfully used as adsorbents of trace metals from water reservoirs. Using such adsorbents can prove to be an excellent alternative for expensive, conventional methods of removing metals from the polluted environment. Rice hulls, sawdust, bagasse, waste from fruits or even weeds can be used as the adsorbent material as well. Chemical modification of these wastes using organic acids, inorganic acids, or oxidizing agents greatly increases the capacity of adsorption of $\mathrm{Cd}, \mathrm{Pb}, \mathrm{Hg}, \mathrm{Cr}, \mathrm{Ni}, \mathrm{Cu}$, and $\mathrm{Zn}$ (Wan Ngah and Hanafiah, 2008; Srinivas and Naidu, 2013). Furthermore, for the process of removal of trace metals from aqueous system, the so-called technology of nanosized metal oxides (NMOs), such as the use of nano-ferric oxides, nano-manganese oxides, nano-aluminum oxides, nano-titanium oxides, nano-magnesium oxides or nano-cerium oxides, can also be applicable. NMOs provide a large surface area and a specific affinity for trace metals. Currently, research in basic sciences related to NMO technology (materials based on metal oxides, granular composite materials) is focused on understanding the mechanisms responsible for the removal of metal ions and is conducted based on modern analytical techniques such as X-ray absorption spectroscopy (XAS), Attenuated total reflectance Fourier transform infrared spectroscopy (ATR-FT-IR), nuclear magnetic resonance (NMR), or mathematical models (Hua et al., 2012; Fu et al., 2014; Zhao et al., 2016a).

The presence of elevated concentrations of arsenic in natural waters around the world is another great problem, and arsenic is toxicologically dangerous due to its nature. Removal of arsenic occurs by oxidation, precipitation, coagulation, membrane filtration, and adsorption (Mohan and Pittman, 2007; Allende et al., 2014). During the process of trace metal removal from contaminated water active carbon, chitosan or zeolite can also be used. These materials are easily available and have a high adsorption capacity (Babel and Kurniawan, 2002; Cardoso et al. 2015; Qi et al., 2015). Recently, bioflocculants have additionally been tested in that regard (Czemierska et al., 2015; Zhao et al., 2016).

\section{Biological methods for the environment treatment}

There are high expectations in the use of effective biological methods appropriate for wastewater treatment. Generally, phytoremediation is the purification technology that is used to purify ground, groundwater, surface water, sludge, and even air, using the natural ability of certain plants to adsorb pollutants or rendering them harmless. These plants are capable to grow in ecosystems contaminated with organic and inorganic materials, adsorbing or biodegrading them. This technology might be an interesting alternative to physicochemical methods adversely affecting the environment in a way that they may contribute to the secondary contamination of the purified matrix. Phytoremediation is also economically justified as it requires less investment outlays while it is an environmentally friendly solution (Cunningham et al., 1995; Raskin et al., 1997; Marques et al., 2009; Hanus-Fajerska et al., 2011, Wiszniewska et al., 
2016). Typically, a natural "phytoremediator" should produce an extensive root system; it should be characterized by a rapid vegetative growth and elevated tolerance to certain types of contaminants. In some cases, such specimens ought to possess the ability to accumulate a few impurities at the same time. So far, in land systems, more than 400 species of plants having the ability to accumulate metal ions were identified. Some of the aforementioned phytoremediators also play an important ecological role in protecting against herbivory (Jhee et al., 2006) or, in contrast, forming mutualistic interactions with some insect species (Ernst et al., 1990). Furthermore, besides the interesting shapes of leaves or enjoyable smells of flowers, the use of phytoremediators enables to aestheticize the landscape due to the formation of a dense vegetation cover. Several different techniques (or modes of action) have been distinguished based on the way in which plants purify the contaminated ecosystems; these are as follows: phytoextraction, phytodegradation, phytostabilization, phytoevaporation, phytofiltration, and blastofiltration. The last two of them are included in the phytoaccumulation techniques in aquatic systems. It is important to mention that the mechanisms of detoxification or removal of impurities from the environment by plants are rather complex and often a result of a combination of different metabolic pathways (Salt et al. 1995; Ghosh and Singh, 2005; Ma rques et al., 2009; Augustynowicz et al., 2010; Hanus-Fajerska et al., 2011).

\section{Possibilities of water quality improvement using phytofiltration}

Among the known phytoremediation techniques, phytofiltration is the most suitable method of removing impurities including trace metal ions from the polluted water. Among aquatic environments that are susceptible to the use of this method are municipal wastewaters (phytofiltration of metals, rhizofiltration of nutrients), effusions of arable lands (ingredients from fertilizers, metal ions, selenium, boron, arsenic, herbicides, and organic pesticides), exudates from waste dumps (metal ions), industrial wastes (trace metals, selenium), exudates from landfills or contaminated ground waters (metal ions, organic compounds). In contrast, rhizofiltration is a separate technique that uses plant roots to absorb and further precipitate accumulated toxic metal ions from groundwaters and contaminated wastewaters. Ab- sorbed impurities are collected in vacuoles of the root cell cortex or are penetrated directly into the root tissues. Finally, they are precipitated on the surface of roots. Rhizofiltration can sometimes be regarded as a variant of phytoextraction, as it can affect the absorption of macro- and micronutrients from water and wastewater. The possibility of using plants to purify municipal wastewaters has even been considered at the beginning of 19th century in Germany (Dushenkow et al., 1995; Krishna et al., 2012). Presently, this technique is mainly used for the removal of trace metal ions and radioactive elements, when present in an aqueous medium at relatively low concentrations. The sorption plays the most important role in the removal of trace metals from the environment when rhizofiltration is used; sorption occurs on the surface of the plant root system. The sorption of pollutants is a complex process due to the physicochemical interactions between the plant and particular kind of remediated substance, depending on chelating and ion exchange processes. Interestingly, these processes may also occur on a dead root tissue (Raskin et al., 1997; Krishna et al., 2012; Islam et al., 2013; Allende et al., 2014). The biological processes linked to active accumulation of xenobiotics in vacuoles or transportation to the aerial plant organs does not affect the efficiency of rhizofiltration greatly (Karen et al., 2009). Although the aquatic environment is a natural habitat for plants used in the process of phytofiltration, more and more attention is paid to the possibility of using terrestrial plants for this purpose. Plants grown in hydroponic and aeroponic cultures are sometimes said to be much more effective in rhizofiltration of contaminants than the typical water plants (Raskin et al., 1997; Fine et al., 2013). However, Agunbiade and coworkers (2009) observed that the concentrations of the metal ions in the tissues of Eichhornia crassipes were much higher than their corresponding concentrations in the water sample with the same unit (Table 1). This indicates that plants accumulate metal ions from contaminated medium and that appropriate plant species could be used as an indicator of biological conditions, which can aid in the purification of the coasts from metal contamination.

Augustynowicz and coworkers (2014) studied the phytoremediation capacity of Callitriche cophocarpa concerning water contaminated with thallium ( $\mathrm{Tl}$ ), cadmium $(\mathrm{Cd})$, zinc $(\mathrm{Zn})$, and lead $(\mathrm{Pb})$ derived from natural environment. After a 10-day incubation period, it was ob- 
Table. 1. Some examples of hyper-accumulating plant species exploited in phytofiltration of trace metals

\begin{tabular}{|c|c|c|c|}
\hline Accumulated element(s) & Species & Family & References \\
\hline $\begin{array}{l}\mathrm{As}, \mathrm{Cd}, \mathrm{Cu}, \mathrm{Cr} \mathrm{Fe}, \mathrm{Mn}, \mathrm{Ni} \\
\mathrm{Pb}, \mathrm{U}, \mathrm{Zn}\end{array}$ & Eichhornia crassipes & Pontederiaceae & Agunbiade et al. 2009 \\
\hline As & Chlorodesmis sp. & Udoteaceae & Jasrotia et al. 2015 \\
\hline As & Cladophora sp. & Cladophoraceae & Jasrotia et al. 2015 \\
\hline $\mathrm{As}, \mathrm{Cd}, \mathrm{Cu}, \mathrm{Pb}, \mathrm{Zn}$ & Eleocharis acicularis & Cyperaceae & Sakakibara et al. 2011 \\
\hline $\mathrm{Cd}, \mathrm{Ta}, \mathrm{Pb}, \mathrm{Zn}$ & Callitriche cophocarpa & Callitrichaceae & Augustynowicz et al. 2014 \\
\hline $\mathrm{Cd}, \mathrm{Cu}, \mathrm{Mn}, \mathrm{Ni}$ & Pistia stratiotes & Araceae & Galal and Farahat 2015 \\
\hline $\mathrm{Cr}$ & Juncus acutus & Juncaceae & Dimitroula et al. 2015 \\
\hline $\mathrm{Hg}, \mathrm{Pb}$ & Azolla pinnata & Azollaceae & Mishra et al. 2009 \\
\hline $\mathrm{Pb}$ & Plectranthus aboinicus & Lamiaceae & Ignatius et al. 2014 \\
\hline $\mathrm{Pb}$ & Carex pendula & Cyperaceae & Yadaw et al. 2011 \\
\hline $\mathrm{U}$ & Phaseolus vulgaris & Fabaceae & Yang et al. 2015 \\
\hline
\end{tabular}

served that shoots of studied C. cophocarpa specimens effectively biofiltrated the water so that it met (for $\mathrm{Cd}$, $\mathrm{Zn}$, and $\mathrm{Pb}$ ) the appropriate quality standards after the treatment. The order of accumulation of the investigated elements by shoots ( $\mathrm{mg} / \mathrm{kg}$ dry weight) is as follows: $\mathrm{Zn}$ $(1120)<\mathrm{Tl}(251)<\mathrm{Cd}(71)<\mathrm{Pb}(35)$ (Table 1). In contrast, Dimitroula and coworkers (2015) investigated the filtration efficiency of Juncus acutus in treating $\mathrm{Cr}(\mathrm{VI})$ contaminated groundwater. Measurements of $\mathrm{Cr}(\mathrm{VI})$ and total $\mathrm{Cr}$ were performed to estimate the rate of removal of these metal ions from the water and concentration in plant tissues. The results support that $J$. acutus is able to filtrate up to $140 \mathrm{~g} / 1$ of $\mathrm{Cr}(\mathrm{VI})$ from the contaminated water. The analysis of chromium content in plant tissues revealed that the majority of $\mathrm{Cr}$ was accumulated by the plants used in described experiment (Table 1), whereas the results of Ignatius and coworkers (2014) showed that Plectranthus amboinicus is tolerant to a wide range of lead concentrations and nutrient deficiency. The plant accumulated considerable amounts of lead, particularly in the roots, and the translocation to the stem and leaf was limited, indicating that the use of aboveground parts of the plant for medicinal purposes was not hindered by its ability to remove lead from the soil or water. The results of their research also indicate that the $P$. amboinicus can be considered for the cleanup of lead-contaminated wastewaters in combination with safe biomass disposal alternatives (Table 1).
Jasrotia and coworkers (2015) determined the effectiveness of aquatic macrophyte and microphytes for phytoremediation of water bodies contaminated with high arsenic concentration. Water hyacinth (Eichhornia crassipes) and two algae (Chlorodesmis sp. and Cladophora $s p$.) found near arsenic-enriched water bodies were used to determine their tolerance toward arsenic and their effectiveness to uptake this ion thereby reducing organic pollution in arsenic-enriched wastewater. Cladophora was found to survive in an environment with an arsenic concentration of up to $6 \mathrm{mg} / \mathrm{l}$, whereas water hyacinth and Chlorodesmis could survive in an environment with arsenic concentrations of up to 2 and $4 \mathrm{mg} / \mathrm{l}$, respectively. It was also found that during a 10-day retention period under ambient temperature conditions, Cladophora could have brought down arsenic concentration from $6 \mathrm{mg} / 1$ to $<0.1 \mathrm{mg} / 1$ (Table 1). In Mishra and coworkers' (2009) study, mercury (Hg) removal capacities of two aquatic macrophytes, Pistia stratiotes and Azolla pinnata, were investigated against the coal mining effluent. These plants reduced mercury from the effluent via phytofiltration and subsequently through accumulation in their tissues. It was found out that the removal rate of $P$. stratiotes and $A$. pinnata was $80 \%$ and $68 \%$, respectively, after 21-days exposure to the effluent containing $10 \mu \mathrm{g} / \mathrm{l}$ of $\mathrm{Hg}$. As $\mathrm{Hg}$ was accumulated from the effluent into the tissues of both aquatic macrophytes, they were proven to be accumulators with a transloca- 
tion factor to shoots of less than one during the entire study. The decreasing Hg content in effluent (from 10 to $2.0 \mu \mathrm{g} / \mathrm{l})$ was reflected by its accumulation in roots $(0.57 \pm 0.02 \mathrm{mg} / \mathrm{g}$ in $P$. stratiotes $)$ and leaves of the experimental plants $(0.42 \pm 0.01 \mathrm{mg} / \mathrm{g}, P$. stratiotes $)$ (Table 1). Sakakibara and coworkers (2011) performed field cultivation experiment to examine the applicability of Eleocharis acicularis to the remediation of water contaminated by trace metals. The highest concentrations of trace metals in the shoots of $E$. acicularis were $20200 \mathrm{mg} \mathrm{Cu} / \mathrm{kg}, 14200 \mathrm{mg} \mathrm{Zn/kg,} 1740 \mathrm{mg} \mathrm{As} / \mathrm{kg}$, $894 \mathrm{mg} \mathrm{Pb} / \mathrm{kg}$, and $239 \mathrm{mg} \mathrm{Cd} / \mathrm{kg}$. The concentrations of $\mathrm{Cu}, \mathrm{Zn}, \mathrm{As}, \mathrm{Cd}$, and $\mathrm{Pb}$ in the shoots correlated with metal or metalloid concentration in the ground in a loglinear fashion up to a certain level; whereas the bioconcentration factor for these elements decreased with their increasing concentrations in the ground as was determined that $E$. acicularis biomass was getting lower. Nonetheless, the results indicated the ability of $E$. acicularis to hyperaccumulate $\mathrm{Cu}, \mathrm{Zn}, \mathrm{As}$, and $\mathrm{Cd}$ under natural conditions, making it a good candidate species for the phytoremediation of water contaminated by trace metals (Table 1). Thayaparan and coworkers' study (2013) showed the potential of Azolla pinnata to remove $\mathrm{Pb}$ (II) from aqueous environment through phytofiltration. Increasing concentrations of lead in the growth medium increased the bioconcentration factor of $A$. pinnata up to an optimum value of 1220 while the relative growth of the plants was significantly decreased. The results of the time course study showed that the efficiency of lead removal depended on the duration of the exposure. The maximum uptake of lead was $1383 \mathrm{mg} / \mathrm{kg}$ of $A$. pinnata dry weight after the four-day treatment, where the lead concentration in the growth medium was reduced by $83 \%$. The authors concluded that $A$. pinnata was a potential candidate for the removal of $\mathrm{Pb}$ from polluted waterways (Table 1 ).

In recent years, various types of technical options of phytofiltration ranging from mats floating on the water surface and maintaining the plant roots in water for plants such as Phragmites australis, Schoenoplectus lacustris, Typha laifolia, Nymphaea alba, Eichhornia crassipes, or Helianthus sp. have been developed (Lee and Yang, 2010; Allende et al., 2014). Very popular systems of existentially economic filtration of sewage are based on cane and other plants of the coastal bodies of water. Another example of using phytofiltration is the formation of strips of trees and shrubs along watercourses, whose job would be to protect these waters against pollution dripping from the fields. Those strips usually consist of several types of plants: species of wetlands, hygrophyte, upland species, and some other optional species.

Phytofiltration is the most commonly used technique for the creation of artificial wetlands, which are mainly used for industrial wastewater treatment primarily burdened by trace metals or additionally high salt content, especially when considering land drainage from mines. Because of the way of discharging sewage, three types of artificial wetlands have been distinguished: the surface, subsurface, and vertical flow systems. In these systems, polluted water is directed through a series of engineered ponds (or marshes), different in construction (and depth) to remove contaminants. The plants grown on artificial wetlands are aquatic or marsh plants belonging, among others, to the following species: Alternathera sessilis, Azolla caroliniana, Eichhornia crassipes, Hippurus vulgaris, Juncus balticus, Lemma minor, Myosotis scrpioides, Pistia stratiotes, and Scripus acutus (Mithembu, 2012; Krishna et al., 2012). Artificial wetlands are among the broadly defined systems that are objects or areas that simulate the work of ecosystems created by man in order to optimize their usefulness in sewage purification in order to protect water resources. In the wetland systems, numerous physical, chemical, and biological processes take place appropriate for this ecosystem; they also include, among others, aerobic and anaerobic decomposition of organic matter by microorganisms, downloading of nutrients and trace metals by plants, hoeing, oxygenation of ground by the roots and rhizomes of plants, destruction of pathogenic organisms by antagonistic marsh microflora, and secretions of the root systems of some plants. The macrophytes have a well-developed system of rhizomes or roots that spread in the ground; therefore, the seepage of wastewater occurs evenly. That is why constructed wetlands do not produce secondary sewage sludge; they can remove organic matter, nutrients, trace metals, and some organic micropollutants. Decomposed dying roots/rhizomes of macrophytes are leaving space for newly grown plant subterranean organs that stabilize the hydraulic conductivity of the bed. Macrophytes should also fulfill the following characteristics: biochemical, physiological, and structural features that allow them to operate in hypoxic conditions, which is important for submerged plant organs 
flooded with water (Sakakibara et al., 2011; Mithembu, 2012).

Undeniable advantages of phytofiltration are: lower cost in comparison with mechanical or physicochemical purification methods of wastewater, smaller amount of obtained waste biomass (relative to the volume of purified water stream), the simplicity of the method, the cleaning performance, and the improvement in the quality of air through the increase in area covered by vegetation. In the temperate climatic conditions, the disadvantages of this method are relatively short growing period of plants, the necessity to select plants species growing well in temperate climate, plants species tolerant to the desired type of impurities to be removed. An additional difficulty is the degree of practical use of the described technology since some alternative methods such as rhizofiltration in hydroponics are in the stage of pilot research, especially those with regard to trace metals (Mithembu, 2012; Krishna et al., 2012).

\section{Conclusions}

We should work hard to achieve a substantial reduction in current contamination level of water resources. A concise overview of numerous applications of phytofiltration techniques reported in this paper demonstrates that there is an effective alternative for the existing physicochemical methods of purifying water reservoirs. Despite some limitations, the advantages are so undeniable that the need of further improvement in the described technology is highly justified.

\section{Acknowledgments}

This research was financed by the Ministry of Science and Higher Education of the Republic of Poland granted to the Institute of Plant Biology and Biotechnology, University of Agriculture in Cracow.

\section{References}

Adress M., Ali S., Rizwan M., Rechman M.Z., Ibrahim M., Abbas F., Farid M., Qayyum M.K., Irshad M.K. (2015) Mechanisms of silicon-mediated alleviation of heavy metal toxicity in plants: a review. Ecotox Environ Saf 199: 186-197.

Adriano D. (2001) Trace elements in terrestrial environments biogeochemistry and risk of metals. Springer Verlag, N.Y.

Agunbiade FO., Olu-Owolabi BI., Adebowale KO. (2009) Phytoremediation potential of Eichornia crassipes in metal contaminated coastal water. Bioresour. Technol 100(19): 4251-4526.
Allende K.L., McCarthy D.T., Fletcher T.D. (2014) The influence of media type on removal of arsenic, iron, and boron from acidic wastewater in horizontal flow wetland microcosmos planted with Phragmites australis. Chem Enginn. J. 246: 217-228.

Augustynowicz J., Grosicki M., Hanus-Fajerska E., Lekka M., Waloszek A., Kołoczek H. (2010) Chromim (VI) bioremediation by acquatic macrophyte Callitriche cophocarpa. Sendtn. Chemosphere 79: 1077-1083.

Augustynowicz J., Tokarz K., Baran A., Płachno B.J. (2014) Phytoremediation of water polluted by thallium, cadmium, zinc and lead with the use of macrophyte Callitriche cophocarpa. Arch. Environ. Cont. Toxicol. 66: 572-581.

Babel S., Kurniawan T.A. (2002) Low-cost adsorbents for heavy metals uptake from contaminated water: a review. J. Hazard. Mater. 97: 219-243.

Cardoso A.M., Paprocki A., Ferret L.S., Azevedo C.M.N., Pires M. (2015) Synthesis of zeolite Na-P1 under mild conditions using Brasilian coal fly ash and its application in wastewater treatment. Fuel 139: 59-67.

Cunningham S.D., Berti W.R., Huang J.W. (1995) Phytoremediation of contaminated soils. Trends Biotechnol. 13: 398403.

Czemierska M., Szcześ A., Jarosz-Wilkołazka A., (2015) Purification of wastewater by natural flocculants. BioTechnologia 96(4): 272-278.

Dimitroula H., Syranidou E., Manousaki E., Nikolaidis N.P., Karatzas G.P., Kalogerakis N. (2015) Mitigation measures for chromium-VI contaminated groundwater - The role of endophytic bacteria in rhizofiltration. J. Hazard Mater. 281: 114-120.

Dushenkov V., Kumar P.B.A.N., Motto H., Raskin I. (1995) Rhizofiltration: the use of plants to remove heavy metals from aqueous streams. Environ Science Technol. 29: 1239-1245.

Ernst W.H.O., Schat H., Verkleij J.A.C. (1990) Evolutionary biology of metal resistance in Silene vulgaris. Evol. Trends Plants 4: 45-51.

Farooq U., Kozinski J.A., Khan M.A., Athar M. (2010) Biosorption of heavy metal ion using wheat based biosorption $A$ review of the recent literature. Bioresource Technol. 101: 5043-5053.

Fine P., Rathod P.H., Beriozkin A., Mingelgrin U. (2013) Uptake of cadmium by hydroponically grown, mature Eucalyptus camaldulensis saplings and the effect of organic ligands. Int. J. Phytoremediat. 15: 585-601.

Fu F., Wang Q.I. (2011) Removal of heavy metal ions from wastewater: A review. J. Environ. Manage 92: 407-418.

Fu F., Dionysiou D.D., Liu H. (2014) The use of zero-valent iron for groundwater remediation and wastewater treatment. J. Hazard Mater 267: 194-205.

Galal T.M., Farakat E.A. (2015) The invasive macrophyte Pistia stratiotes $L$. as a bioindicator for water pollution in Lake Mariut, Egypt. Environmental Monitoring and Assessment. Environ. Monit. Asses. 187: 701. DOI 10.1007/ s10661-015-4941-4. 
Ghosh M., Singh S.P. (2005) A review on phytoremediation of heavy metals and utilization of it's by products. Energy Environ. Sci. 6(04): 214-231.

Hanus-Fajerska E., Augustynowicz J., Muszynska E., Kozminska A. (2011) Organisms useful in environment remediation from excessive concentration of metallic elements. Environ. Prot. Nat. Res. 50: 180-192.

Hashim M.A., Mukhopadhyay S., Sachu J.N., Sengupta B. (2011) Remediation technologies for heavy metal contaminated groundwater. J. Environ. Manage. 92: 2355-2388.

Hua M., Zhang S., Pan B., Zhang W., Lv L., Zhang Q. (2012) Heavy metal removal from water/wastewater by nanosized metal oxides. J. Hazard. Mater. 212: 317-331.

Ignatius A., Arunbabu V., Neethu J., Ramasamy E.V. (2014) Rhizofiltration of lead using an aromatic medicinal plant Plectranthus amboinicus cultured in a hydrophonic $n u-$ trient film technique (NFT) system. Environ. Sci. Pollut. Res. Int. 21(22): 13007-13016.

Islam M.S., Uneo Y., Skider M.T., Kurasaki M. (2013) Phytofiltration of arsenic and cadmium from the water environment using Micranthemum umbrosum (J.F. Gmel) S.F. Blake as a hyperaccumulator. Inter. J. Phytoremediat. 15: 1010-1021.

Jasrotia S., Kansal A., Mehra A. (2015) Performance of aquatic plant species for phytoremediation of arsenic contaminated water. Appl. Water Sci. DOI 10.1007/13201-015-0300-4.

Jhee E.M., Boyd R.S., Eubanks M.D., Davis M.A. (2006) Nickel hyperaccumulation by Streptanthus polygaloides protect against the folivore Plutella xylostella (Lepidoptera: Plutellidae). Plant Ecol. 183: 91-104.

Kabata-Pendias A., Pendias H. (2001) Trace elements in soils and plants, 3rd edn. CRC Press, Boca Raton, FL.

Karen E., Gerhard T., Xiao-Dong H., Bernard R., Bruce M. (2009) Phytoremediation and rhizoremediation of organic soil contaminants: potential and challenges. Plant Sci. 176: 20-30.

Katsou E., Malamis S., Haralambous K.J. (2011) Industrial wastewater pre-treatment for heavy metal reduction by employing a sorbent-assisted ultrafiltration system. Chemosphere 82: 557-564.

Krishna R., Fulekar M.H., Patakg B. (2012) Rhizofiltration: a green technology for remediation of heavy metals. Inter. J. Innov. Bio-Sciences 2(4): 193-199.

Kurniawan T.A., Chan G.Y.S., Lo W., Babel S. (2006) Physicochemical treatment techniques for wastewater laden with heavy metals. Chem. Eng. J. 118: 83-98.

Lee M., Yang M. (2010) Rhizofiltration using sunflower (Helianthus annuus L.) and bean (Phaseolus vulgaris $L$. var. vulgaris) to remediate uranium contaminated groundwater. J. Hazard. Mater. 173: 589-596.

Marques A.P., Rangel A.S., Castro P. M.L. (2009) Remediation of heavy metal contaminated. Environ. Sci. Technol. 39: 622-654.

Mishra V.K., Tripathi B.D., Kim K.H. (2009) Removal and accumulation of mercury by aquatic macrophytes from an open cast coal mine effluent. J. Hazard Mater. 172(2-3): 749-754.
Mithembu M.S. (2012) Nitrogen and Phosphorus Removal from Agricultural Wastewater Using Constructed Rhizofiltration in Durban, South Africa. J. Agr. Sci. Technol. 2: 1142-1148.

Mohan D., Pittman Jr. C.U. (2007) Arsenic removal from water/wastewater using adsorbents - a critical review. J. Hazard. Mater. 142: 1-53.

Nagajyoti P.C., Lee K.D., Sreekanth T.V.M. (2010) Heavy metals, occurrence and toxicity for plants: a review. Environ. Chem. Lett. 8: 199-216.

Rahman M.A., Hasegawa H. (2011) Aquatic arsenic: phytoremediation using floating macrophytes. Chemosphere, 83(5): 633-646.

Raskin I., Smith R.D., Salt D.E. (1997) Phytoremediation of metals: using plants to remove pollutants from the environment. Curr. Opin. Biotech. 8: 221-226.

Rizwan M., Ali S., Ibrahim M., Farid M., Adrees M., Bharwana S.A., Rehman M.Z., Qayyum M.F., Abbas F. (2015) Mechanisms of silicon-mediated alleviation of drought and salt stress in plants: a review. Environ. Sci. Pollut. Res. Doi: $10.1007 / \mathrm{s} 11356-015-5305-\mathrm{x}$.

Sakakibara M., Ohmoi Y., Thi Hoang Hi N., Saro S., Sera K. (2011) Phytoremediation of heavy metal contaminated water and sediment by Eleocharis acicularis. Clean-Soil, Air, Water 39(8): 735-741.

Salt D.E., Blaycock M., Kumar N.B.A., Dushenkov V., Ensley B.D., Chet I., Raskin I. (1995) Phytoremediation: A novel strategy for the removal of toxic metals from the environment using plants. Biotech. 13: 468-474.

Srinivas Raju R.K. Naidu S.V. (2013) A Review on Removal of Heavy Metal Ions from Wastewater by Rice Husk as an Adsorbent. J. Chem. Biol. and Phys. Sci. 2(3): 602-606.

Thayaparan M., Iqbal S.S., Chathuranga P.K.D., Iqbal M.C. M. (2013) Rhizofiltration of Pb by Azolla pinnata. International Journal of Environmental Science 3(6): 1811-1821.

Wan Ngah W.S., Hanafiah M.A. K M. (2008) Removal of heavy metal ions from wastewater by chemically modified plant wastes as adsorbents: A review. Bioresource Technol. 99: 3935-3948.

Wiszniewska A., Hanus-Fajerska E., Muszyńska E., Ciarkowska K. (2016) Natural organic amendments for improved phytoremediation of polluted soils: a review of recent progress. Pedosphere 26(1): 1-12.

Wuana R.A., Okieimen F.E. (2011) Heavy metals in contaminated soils: a review of sources, chemistry, risks and best available strategies for remediation. ISRN Ecol. Doi: 10.5402/2011/402647.

Yadav B.K., Siebel M.A., van Bruggen J.J.A. (2011) Rhizofiltration of a heavy metal (lead) containing wastewater using the wetland plant Carex pendula. Clean Soil Air Water 39: 467-474.

Yang M., Jawitz J. W., Lee M. (2015) Uranium and cesium accumulation in bean (Phaseolus vulgaris L. var. vulgaris) and its potential for uranium rhizofiltration. Jour. Environ. Radioact. 140: 42-49. 
Zaheer I.E., Ali S., Rizwan M., Farid M., Shakoor M.B., Gill R.A., Najeeb U., Iqbal N., Ahmad R. (2015) Citric acid assisted phytoremediation of copper by Brassica napus $L$. Ecotoxicol. Environ. Saf. 120: 310-317.

Zhao M., Xu Y., Zhang Ch., Rong H., Zeng G. (2016a) New trends in removing heavy metals from wastewater. App. Microbiol. Biotechnol. 100: 6509-6518.
Zhao H., Zhong Ch., Chen H., Yao J., Tan L., Zhang Y., Zhou J. (2016b) Production of bioflocculants prepared from formaldehyde wastewater for the potential removal of arsenic. J. Environ. Managem. 172: 71-76. 